\title{
Redox controls on trace element mobility during shale weathering from microscale analyses
}

\author{
SERGio CARRERO ${ }^{1,2}$, BHAVNA ARORA ${ }^{1}$, S. SLOTZNICK ${ }^{2}$, \\ CARL STEEFEL ${ }^{1}$, J. BANFIELD ${ }^{2}$, BEN GILBERT ${ }^{1}$ \\ ${ }^{1}$ Lawrence Berkeley Laboratory, CA, ${ }^{2} \mathrm{UC}$ Berkeley, CA
}

Bedrock weathering in mountain watersheds releases metals and nutrients into ground and surface water, especially in mineralized shale bedrock with high sulfide mineral content. These reactions can degrade water quality in the watershed and downstream. Although weathering reaction effects have been described in many different types of bedrocks, including shale, the chemical and mineralogical characterization and models have been focused to describe the weathering front at metric scale. However, the heterogeneity of shale rocks channels the weathering fluid through bending fractures, focusing the alteration at fracture surface and gradually progressing inside the rock. We are studying this process at Esat River in the Upper Colorado River Basin that is situated on Mancos formation, a black shale with variable sulfide content. We seek to model the micro-scale reaction network to predict the mobility of trace elements between the bedrock and the ground water, focusing on the influences of redox and $\mathrm{pH}$. Here we report the analysis and interpretation of the weathering profile observed around bending fractures at different depths in a borehole traversing the water table.

Microscale weathering profiles at any depth above pristine shale display groundwater diffusion inside the shale, altering primarily sulfide and secondary carbonate minerals. However, carbonate precipitation at fracture surface, pyrite replacement by iron oxide, as well as clay and plagioclase transformations, provide sinks for mobilized contaminants, such as $\mathrm{Fe}$ and $\mathrm{Mn}$, especially in profiles located in deep areas closer to pristine shales. 1D CrunchFlow models reproducing weathering condition at different depths indicate that weathering reaction occurs under circumneutral $\mathrm{pH}$ in equilibrium with carbonate, where groundwater could get oversaturate in calcite and $\mathrm{Mn}$ oxide. However, metal and trace element concentration in groundwater water is low during alteration reaction indicating that most of these element are retaining on the rock. In particular, the distribution and speciation of of redox-active metals such as Se indicate that sorption and secondary mineral precipitations are tighltly controled by in situ geochemical conditions during weathering. 